\title{
Root detection by resistivity imaging and physiological activity with the dead-end trench on three clones of cocoa (Theobroma cacao)
}

\author{
CANGGIH NAILIL MAGHFIROH ${ }^{1}$, EKA TARWACA SUSILA PUTRA ${ }^{1, \bullet}$, ENDANG SRI DEWI HS $^{1,2}$ \\ ${ }^{1}$ Department of Agronomy, Faculty of Agriculture, Universitas Gadjah Mada. Jl. Flora No. 1, Bulaksumur, Sleman55281, Yogyakarta, Indonesia. \\ Tel./fax.: +62-274-563062, `email: eka.tarwaca.s@ugm.ac.id \\ 2Department of Agrotechnology, Faculty of Agriculture, Universitas Sintuwu Maroso. J1. Pulau Timor No.1, Gebang Rejo, Poso 94612, Central \\ Sulawesi, Indonesia
}

Manuscript received: 27 December 2019. Revision accepted: 27 May 2020.

\begin{abstract}
Maghfiroh CN, Putra ETS, Dewi HSES. 2020. Root detection by resistivity imaging and physiological activity with the deadend trench on three clones of cocoa (Theobroma cacao). Biodiversitas 21: 2794-2803. Indonesia is one of the largest cocoa production countries in Southeast Asia, but has low average productivity (982 kg/ha) based on Indonesian Plantation Statistics (2017). Productivity increase effort by giving dead-end trenches that applied to collect organic material, accommodate surface runoff sediments, prevent erosion, and maintain nutrient availability. Dead-end trench had an impact on root cutting and improve rooting. Clone is very influential on cocoa (Theobroma cacao L.) yield. The superior clones recommended are clones RCC-70, RCC-71, and KKM-22, which have high productivity and are resistant to pests and diseases. The objectives of this research were (i) to detect the presence of roots by resistivity imaging (ii) to study the effects of dead-end trench application on physiological activities of cocoa leaves and yields of three clones (RCC-70, RCC-71, and KKM-22); (iii) to determine which cocoa clone (s) performed a significant yield increase with the application of dead-end trench. Research was conducted in August 2018-April 2019 at PT. Pagilaran cocoa plantation in North Segayung Production Unit, subdistrict Tulis, Batang, Central Java. The experiment was arranged in a randomized complete design with two factors and three blocks as replications. The first factor was dead-end trench application (with or without dead-end trench application) and the second factor was cocoa clones (RCC-70, RCC-71, and KKM-22). This study showed that dead-end trench applications affected plant roots based on the interpretation results of geoelectric-resistivity measurements. Dead-end trench application significantly affected chlorophyll a, stomatal conductance, transpiration, and $\mathrm{H}_{2} \mathrm{O}$ leaf content. Dead-end trench application has no significant effect on the content of chlorophyll b, total chlorophyll content, nitrate reductase activity, stomatal density, $\mathrm{CO}_{2}$ leaf content, and photosynthesis rate.
\end{abstract}

Keywords: Cocoa, dead-end trench, KKM 22 clone, physiological activity, RCC 70 clone, RCC 71 clone

\section{INTRODUCTION}

Cacao (Theobroma cacao L.) is a tropical perennial crop cultivated in West Africa, Southeast Asia, and Latin America. Indonesia is one of the countries that have the largest production in Southeast Asia, followed by Papua New Guinea and Latin America. The largest productions are in Brazil, Ecuador, and Columbia (Lahive et al. 2019). Cacao is classified into 3 major groups namely Criollo, Forastero, and Trinitario based on morphology, genetic character, and geographic area. Cacao Criollo is the first domesticated and widely cultivated cacao in North America and South America. Cacao variety Forastero comes from the lower Amazon basin, while cacao trinitario is a cross between Cacao Criollo and Forastero. Cacao has genetic variability in morphological and physiological properties. (Almeida and Valle 2007). Cacao cultivation is carried out intensively to produce cocoa butter and cocoa powder for industrial needs (Li et al. 2013). Factors that influence crop production are internal factors and external factors.

Soil is an environmental factor that influences plant growth and development. High rain intensity triggers erosion and threaten crop production (Dimtsu 2018). The dead-end trench application for soil conservation is very important. The dead-end trench supports the improvement of physical and chemical conditions in the soil, hold surface sediments, nutrients, and nutrients. Land rehabilitation technology by making trench contours increasing soil infiltration and moisture longer in the soil profile (Kurothe et al. 2014). Sloping land is a top priority for conservation which not only supports sustainable crop production, but also to mitigate various environmental damage (Tang et al. 2014). Cacao plants are very sensitive to water shortages, cacao plantations must have good drainage. The availability of nutrients in the topsoil will be very important at $1.5 \mathrm{~m}$ depth to support the root growth system. Plants need large amount of roots to absorb nutrients (Fonkeng 2014).

Clone is internal factor very affecting cocoa yield. The superior clones recommended by coffee and cocoa research center (Puslitkoka)are clones RCC70, RCC71, and KKM 22 which have high productivity and are resistant to pests and diseases. The productivity of these clones is high, RCC70 clone produces 2,287 kg/ha, RCC71 clone produces 2,284 kg/ha, and KKM22 clone produces 2,42 $\mathrm{kg} / \mathrm{ha}$ (Rajoniati 2006). RCC 70 and RCC 71 clones are Forastero clones, while KKM 22 clones include Trinitario clones. The main target of breeding is to look for clones that are resistant to biotic stresses, ie, against disease and to obtain physiological properties. Some recent studies regarding photosynthesis efficiency are important factors determining the yield of plants (Wickrama and Dunwell 
2018). The physiological activities of cocoa plants are associated with high biomass production, photosynthesis rate, stomatal conductance, high chemical activity, and effectivity of intracellular water. Optimization of plant performance must be improved in a variety of growing environmental conditions (Alban et al. 2015). Genetic and physiological activities are the main factors that affect flowering time, reproduction, and productivity (Adjaloo et al. 2012). The influence of the dead-end trench on the physiology of cacao plants improving production and increasing income economically, but the information on this is limited. Therefore this research is focused to find out the effect of giving the dead-end trench on the physiological activities of cocoa planted in plantation areas.

The objectives of this research were (i) detect the presence of roots by resistivity imaging (ii) to study the effects of dead-end trench application on physiological activities of cocoa leaves and yields of three clones (RCC70, RCC-71, and KKM-22); (iii) to determine which cocoa clone (s) performed a significant yield increase with the application of dead-end trench.

\section{MATERIALS AND METHODS}

\section{Study area}

The study was conducted in August 2018-April 2019 at PT. Pagilaran Cocoa Plantation in North Segayung

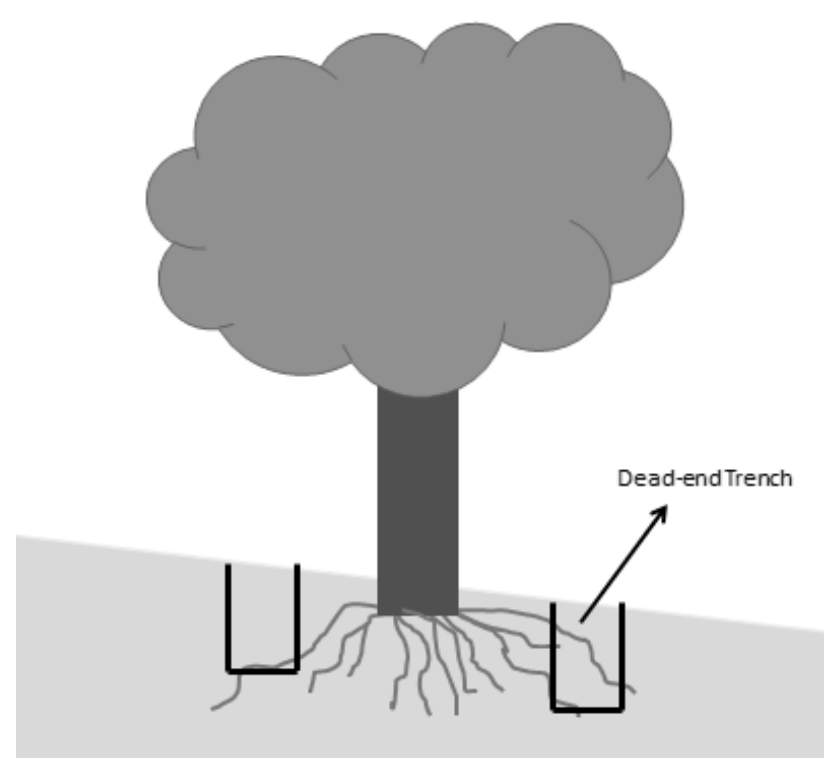

Figure 1. Dead-end trench standard
Production Unit, Subdistrict of Tulis, Batang District, Central Java, Indonesia. The experiment was arranged in a randomized complete design with two factors and three blocks as replications. The first factor was dead-end trench application (with or without dead-end trench application) and the second factor was cocoa clones (RCC 70, RCC 71, and KKM 22). The treatment in each block used three cocoa (Theobroma cacao L.) plants as samples, the number of plants used by 56 plants. The parameters observed were soil conditions with the geo-elistric resistivity method, content of chlorophyll a, content of chlorophyll b, total chlorophyll content, transpiration, nitrate reductase activity, stomatal density, stomatal conductance, $\mathrm{CO}_{2}$ leaf content, $\mathrm{H}_{2} \mathrm{O}$ leaf content, and photosynthesis rate. Covenants carried out to a constant root dry weight.

\section{Procedures}

\section{Dead end-trench application}

Dead-end trench layout used in the research according to Figures 1, 2, and 3. The dead-end trench of a certain size was made parallel to a contour line to intercept runoff. The purpose of dead-end trench application was to increase the yield of cocoa plants and made around the plant to support plant roots. The technical requirements of the dead-end trench size, length $100 \mathrm{~m}$, width $30 \mathrm{~cm}$, and height 50 $\mathrm{cm}$.

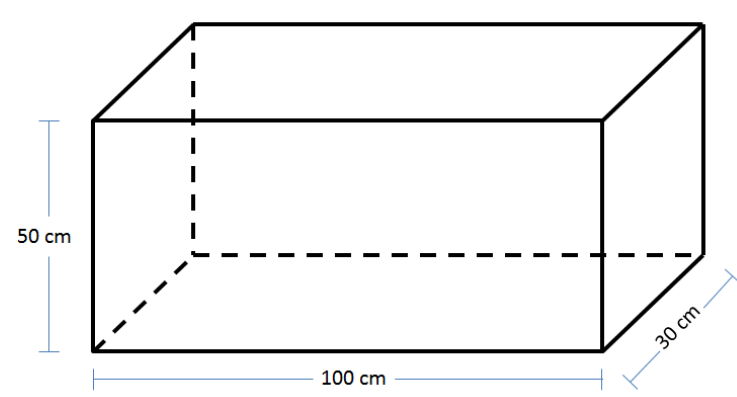

Figure 2. Dead-end trench layout

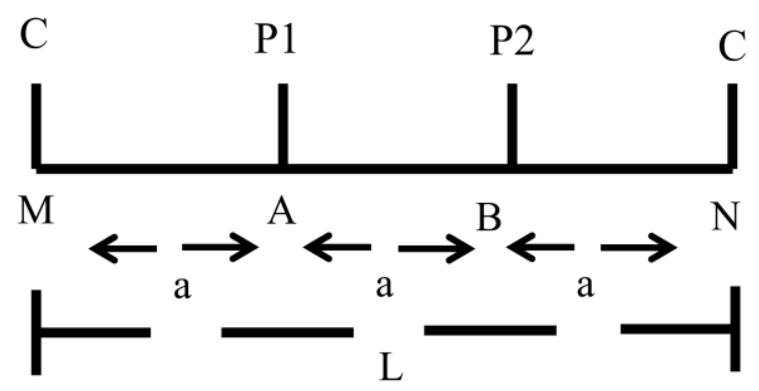

Figure 3. Wenner configuration current and potential electrodes 
The distance $\mathrm{AM}=\mathrm{NB}=\mathrm{a}$ and the distance $\mathrm{AN}=\mathrm{MB}$ $=2 \mathrm{a}$, was obtained:

$$
\mathrm{K}_{\mathrm{W}}=\frac{2 \pi}{\left[\frac{1}{\mathrm{a}}-\frac{1}{2 a}\right)-\left(\frac{1}{2 a}\right.} \text { and } \mathrm{K}_{\mathrm{W}}=2 \pi \text {. }
$$

Geometry factors for the Wenner configuration following this formula:

$$
K_{w}=2 \pi \text { and } \rho_{w}=K_{w} \cdot R \text {. }
$$

Processing of data results of the geoelectric test using the non-linear least square optimization method with 2D inversion available in Res2Dinv software. The data obtained were visualized in a table to make it easier to read the information from the analysis.

Where: N: first point; B: second point; A: third point; M: fourth point; P1: resistivity 1; P2: Resistivity 2; C: start point/last point; a: distance; $\mathrm{K}_{\mathrm{w}}$ : Wenner Configuration, $\mathrm{R}$ : Exploration of total distance (Wijaya 2015).

\section{Resistivity imaging}

Detection of the effect of dead-end trench on active cocoa roots was done using the resistivity geoelectric method. According to Wijaya (2015), the principle of resistivity geoelectric method was to conduct an electric current injection from the ground surface with the electrodes that had been arranged, and then the potential difference was measured with other electrodes. The voltage data obtained to estimate the resistance value. The configuration method used the Wenner configuration (Figure 3$)$. The Wenner configuration spacing was same $\left(\mathrm{r}_{1}\right.$ $=r_{4}=a$ and $\left.r_{2}=r_{3}=2 a\right)$. Specifications of the equipment have consisted of Uninterruptible Power supply device (APC BX1100LIMS), electrodes, voltage, and current measuring devices (Sanwa Digital Multitester CD800a, Japan). Electrodes were made of iron with a diameter of 1 $\mathrm{cm}$ and a length of $20 \mathrm{~cm}$. Electrodes were made of iron with diameter of $1 \mathrm{~cm}$ and a length of $20 \mathrm{~cm}$. The electrodes were electrified, then, current and voltage were read on the instrument.

The distance used: the distance between the current electrodes was three times the distance of the potential electrode, the potential distance from the sounding point was $2 / a$, then the distance of each current electrode to the sounding point was $2 / 3$ a. The depth target achieved in this method was 2/a. Data field acquisition, the current and potential electrode arrangement were placed symmetrically with the sounding point.

\section{Physiology}

Observations on the rate of photosynthesis, $\mathrm{CO}_{2}$ content, and $\mathrm{H}_{2} \mathrm{O}$ of the leaves were measured using a Photosintetic Analyzer LI-6400 Version 5 made in USA. Measurements were made on the third leaf from the shoot and taken at 10-12 am. Measurements of transpiration were made by first cleaning the leaves and then taking $10 \mathrm{~cm}$ diameter cobalt paper, which had been affixed to a celluloid sheet, then clipped to the edge of the leaf so that each leaf's upper and lower surface was sandwiched by cobalt paper. The time needed to change the paper blue to pink indicates the rate of water loss from the leaf-covered by the paper (Loveless 1983).

Nitrate reductase activity was measured from leaf samples. Leaf samples were taken from the third leaf (counted from the tip of the branch), the sample was collected in the morning then the sample washed and cut into small pieces. A total of $200 \mathrm{mg}$ of leaf samples that had been weighed put into a buffer solution. Buffer solution, $\mathrm{Na}_{2} \mathrm{HPO}_{4}$, and $2 \mathrm{H}_{2} \mathrm{O}$ at $\mathrm{pH} 7.5$, every $5 \mathrm{~mL}$ was put into a dark tube then closed and soaked for 24 hours. After 24 hours, the buffer solution was removed and replaced with a new solution of $5 \mathrm{~mL}$, then added $0.1 \mathrm{~mL}$ of $5 \mathrm{M} \mathrm{NaNO}_{3}$ to each dark tube. The time of addition of $\mathrm{NaNO}_{2}$ was stated as incubation time 0 . Incubation was carried out for 2 hours. Meanwhile, another test tube filled with reagent of $0.2 \mathrm{~mL}$ of $1 \%$ sulfanilamide dissolved in $\mathrm{HCl}$ and $0.2 \mathrm{~mL}$ of $0.02 \%$ napthylethylendiamide solution. Then $0.1 \mathrm{~mL}$ of the filtrate that had been incubated for 2 hours was put into a test tube filled with reagent, $\mathrm{HCl}$, and napthylenediamide solution. The test tube was shaken until the filtrate mixed to speed up the reaction. The solution let about 15 minutes until $\mathrm{NO}_{2}$-reduction occurs with a coloring reagent changing into pink color. Furthermore, 2.5 $\mathrm{mL}$ of distilled water was added to the test tube as a color thinner. The solution in the test tube measured by using the spectrophotometer cuvette to observe its absorbance at a wavelength of $540 \mathrm{~nm}$ (Listyawati 1994).

$$
\mathrm{NRA}=\frac{\text { sample absorbance }}{\text { standard absorbance }} \times 50 \times \frac{1000}{B B} \times \frac{1}{W 1} \times \frac{1}{1000}
$$

Where;

Standard absorbance: 0.0142

BB: Wet weight (mg)

W1: incubation time (hours)

Identification of leaf stomata morphological characters at $08.00-11.00$ by making stomata mold using clear nail polish on the leaf underside. The stomata mold peeled with clear tape and observed using a microscope. Observation of the stomata was carried out using an ocular lens with a net micrometer at a magnification of 100 times. The width of the stomatal conductance was observed using a fence micrometer at a magnification of 40 times (Hidayat 2009).

Observation of chlorophyll content in leaves was done by taking leaf samples from the outer canopy. Each leaves taken 1 gram and then ground until smooth and extracted using $100 \mathrm{~mL}$ acetone until all the chlorophyll dissolved. Chlorophyll extract was filtered and put into a cuvette and absorbance measuring with wavelengths 645 and $663 \mathrm{~nm}$. Chlorophyll a and chlorophyll b levels calculated using the formula (Harborne 1998):

Chlorophyll total $(\mathrm{mg} / \mathrm{L})=((20.2$ OD 645) $+(8.02 \times$ OD 663) $) \times 0.02$ Chlorophyll a $(\mathrm{mg} / \mathrm{L})=((12.7 \times$ OD 663) $-(2.69 \times$ OD 645) $) \times 0.02$

Chlorophyll b $(\mathrm{mg} / \mathrm{L})=((22.9 \times$ OD 645$)-(4.68 \times$ OD 663$)) \times 0.02$ 


\section{Data analysis}

Data were analyzed by using analysis of variant (ANOVA) with $\alpha=5 \%$. If the results of variance analysis indicated an interaction between the factors tested, then a simple influence analysis was performed. However, if there was no interaction between factors, the follow-up test is Fisher's Least Significant Difference (LSD). Data analysis was performed using SAS 9.4 software. Geo-electric resistivity data analysis was created by using Res2Dinv software.

\section{RESULTS AND DISCUSSION}

\section{Root detection by resistivity imaging}

Underground condition was observed using resistivity geoelectricity, the results of the interpretation consisted of three parts. The first part was the resistivity distribution that had been measured in the field, the second part was the apparent resistivity distribution, the third was the resistivity distribution after inversion. The third image was an image showing the actual resistivity. The law of Ohm is the basis of an electrical circuit so that it can calculate the required resistance value. The resistivity distribution was very important to know to calculate its potential on the surface and in the medium (Rolia and Sutjiningsih 2018).

In Figure 4 shows the soil consists of 3 different resistivities of 1396-1636 $\Omega \mathrm{m}$ (low resistivity), 1636-2076 $\Omega \mathrm{m}$ (moderate resistivity), and 2076-2432 $\Omega \mathrm{m}$ (high resistivity). The depth of $0.0625-0.319 \mathrm{~m}$, dominated by blue and green colors which indicate low and moderate resistivity. The depth of $0.319-1.2 \mathrm{~m}$ had variation in resistivity from moderate to high, indicated by the number of colors between green and a little red to purple. This shows that the depth of the soil dominated by medium resistivity and a small portion of high resistivity. There were variations in the distribution of water in the soil at the study site. This was indicated by the change in resistivity values from high, medium, and low. The depth of 0.0625 $0.319 \mathrm{~m}$; it is dominated by blue which indicates that there was a large amount of groundwater content. The depths of $0.319-1.2 \mathrm{~m}$, there was a variation in resistivity from moderate to high that indicated by the number of colors between green and red which indicates the least soil water content. Application the dead-end trench provides more groundwater content compared to that not given the deadend trench.

Clone RCC71 on the dead-end trench application, the results shown in Figure 5. The depth 0.0625-0.319 m, the dominant color was green, while for blue there are only certain areas. The depths of 0.319-0.622 $\mathrm{m}$ the most dominant color was yellow so it belongs to high resistivity. At a depth of $0.622-1.2 \mathrm{~m}$, the most dominant color was brown to red so it also belongs to high resistivity. In the measurement results with the resistivity geoelectric method, the high resistivity is at 2025-2404 $\Omega \mathrm{m}$, the medium resistivity was $1566-2025 \Omega \mathrm{m}$, and the low resistivity is $1319-1566 \Omega \mathrm{m}$. The distribution of resistivity in the RCC71 the dead-end trench application various from high resistivity to low resistivity.

Based on the results of the inversion shows that at a depth of $0.0625-0.319 \mathrm{~m}$ was dominated by blue which indicated low resistivity. At depths of $0.319-1.2 \mathrm{~m}$, there were variations in resistivity from moderate to high that indicated by the number of colors between green and red. The use of the dead-end trench had an effect on resistivity that estimated the presence of more water content at low resistivity. The results obtained in track 2 were not much different from track 1, namely in shallow submerged soils that had higher soil moisture content, especially in the dead-end trench.

Observation of soil conditions using the resistivity geoelectric method obtained results in Figure 6. Based on the results of the inversion conducted a high resistivity value between 1732-2381 $\Omega \mathrm{m}$, Figure 6 marked with yellow to purple. The resistivity value of 1874-1732 $\Omega \mathrm{m}$ shown in light green to dark green was the medium resistivity. Low resistivity was shown in dark blue to light blue (781-1874 $\Omega \mathrm{m})$. At a depth of $0.0625-0.319 \mathrm{~m}$, it is dominated by brown, but a small portion was blue which indicates low to high resistivity. The depths $0.319-1.2 \mathrm{~m}$ indicated by brown to purple which indicates that at that depth it had high resistivity.

Based on the results of the inversion carried out that the condition without the dead-end trench caused not too much variation in resistivity. The resistivity conditions tend to be high and evenly distributed at every depth. The high resistivity value indicated the least water content in the soil. In the deeper depths of soil the higher the resistivity value, it was caused by the lack of water content. The decomposition of ions occurred when there was sufficient water so that when given an electric voltage it was easier to deliver it.

Observation of the soil conditions using the resistivity geoelectric method obtained the results of Figure 7. Based on the results of the inversion conducted a high resistivity value that is between 1846-2557 $\Omega \mathrm{m}$, wherein Figure 8 marked with yellow to purple. The resistivity values 1168 $1846 \Omega \mathrm{m}$ shown in light green to dark green were medium resistivity. Low resistivity was shown in dark blue to light blue (846-1168 $\Omega \mathrm{m})$. The depth 0.0625-0.319 m, it was dominated by brown, but a small portion was blue which indicates low to high resistivity. The depths of 0.319-1.2 m indicated by brown to purple which indicates that at that depth it has high resistivity.

Based on the results of the inversion, there was no significant difference between track 1 and track 2 . The second track also showed that without treatment, the soil moisture content became less when compared to the treatment using the dead-end tranch. The depth of 0.319 $0.622 \mathrm{~m}$ it indicates that there was only a moderate soil content. While the deeper the depth of the soil, the less water there was. 

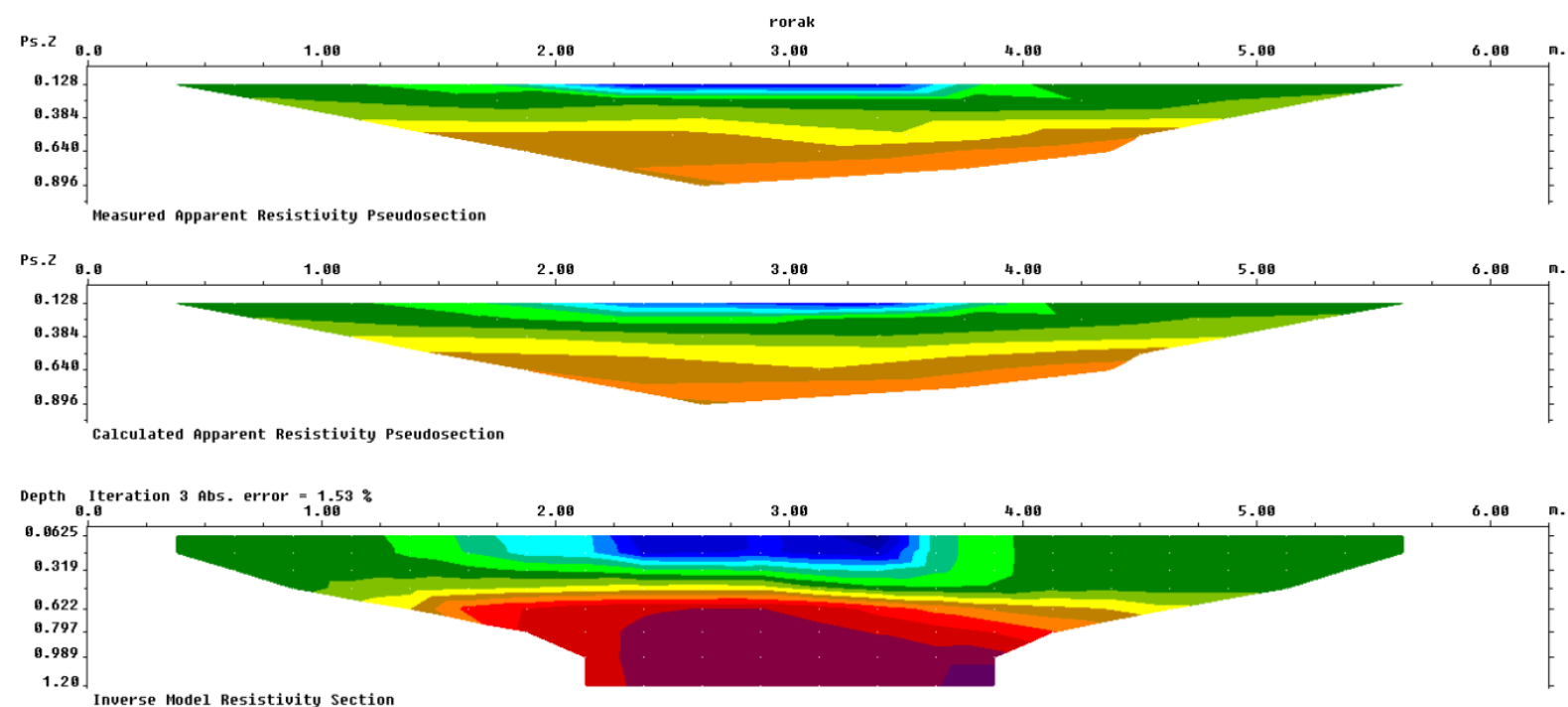

$\square_{1396}^{\text {Inverse Mode1 Resistivity Section }}{ }_{1511}^{\square_{1636}^{1771}} \square_{1917}^{1917} \square_{287} \square_{2247} \square_{2432} \square$

Unit electrode spacing $9.250 \mathrm{~m}$.

Figure 4. Track 1 with dead-end trench application

Notification for Figure 4. Interpretation result of track 1 with dead-end trench application

\begin{tabular}{lll}
\hline No. & Contour color & Resistivity value \\
\hline 1 & & $1396-1636 \Omega \mathrm{m}$ \\
2 & & $1636-2076 \Omega \mathrm{m}$ \\
3 & & $2076-2432 \Omega \mathrm{m}$ \\
\hline
\end{tabular}
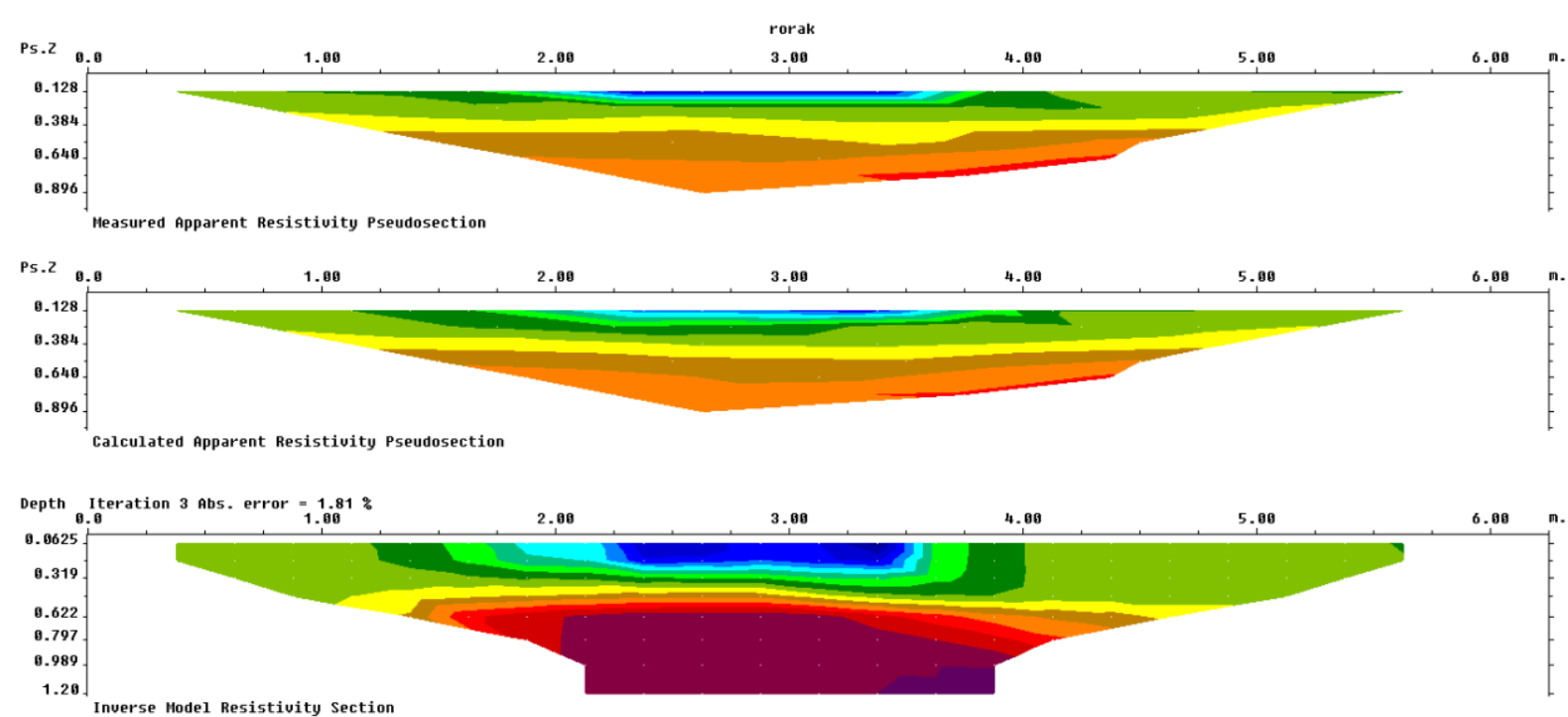

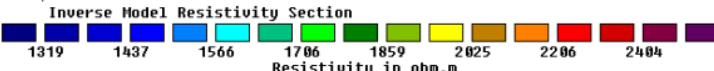

Figure 5. Track 2 with dead-end trench application

Notification for Figure 5. Interpretation result of track 2 with dead-end trench application

\begin{tabular}{lll}
\hline No. & Contour color & Resistivity value \\
\hline 1 & & $1319-1566 \Omega \mathrm{m}$ \\
2 & & $1566-2025 \Omega \mathrm{m}$ \\
3 & & $2025-2404 \Omega \mathrm{m}$ \\
\hline
\end{tabular}



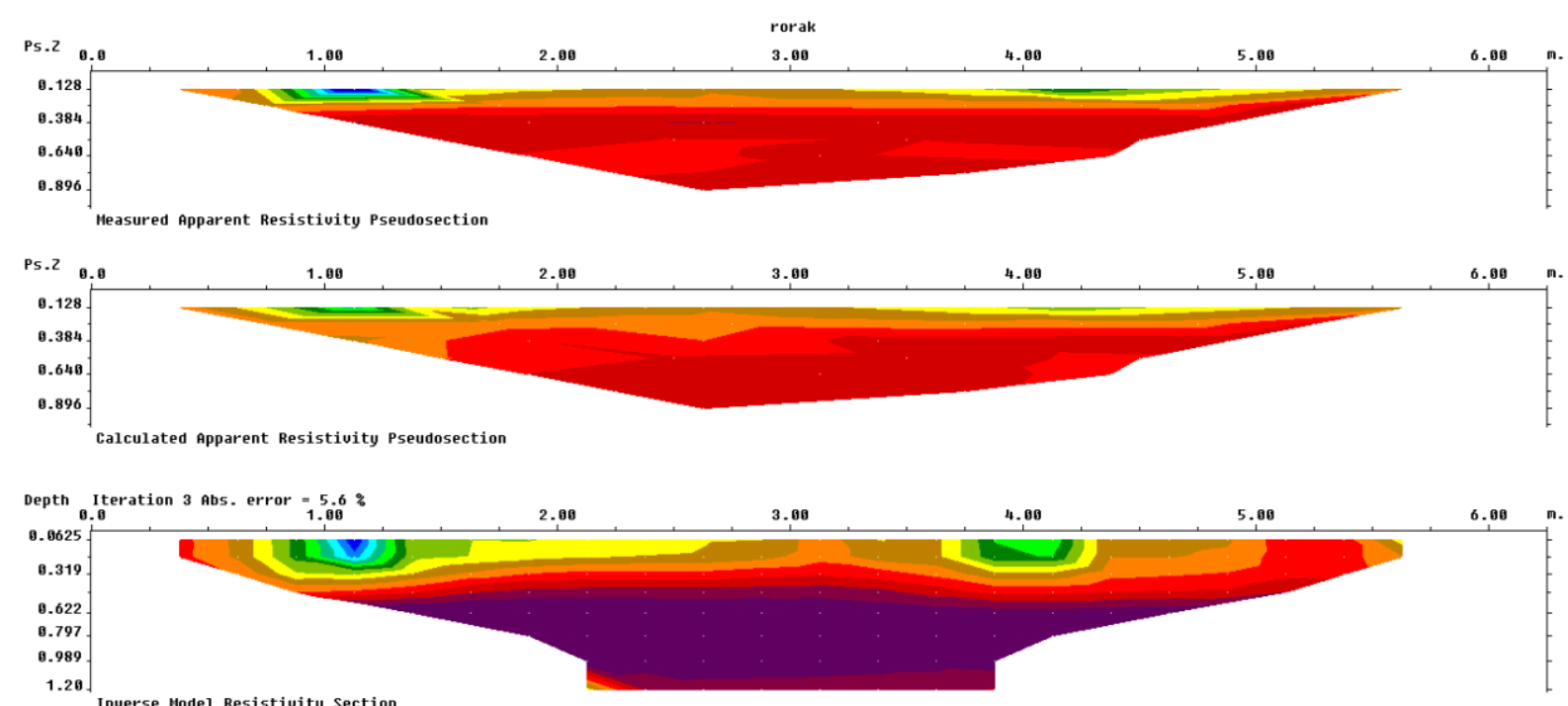

$\square_{781}^{\text {Inverse Hodel Resistivity Section }}{ }_{916}^{1074} \square_{1259}^{1477} \square_{1732} \square_{2031} \square_{2381} \square$

Unit electrode spacing $9.258 \mathrm{n}$

Figure 6. Track 1 without dead-end trench application

Notification for Figure 6. Interpretation result of track 1 without dead-end trench application

\begin{tabular}{lll}
\hline No. & Contour color & Resistivity value \\
\hline 1 & & $781-1874 \Omega \mathrm{m}$ \\
2 & $\square$ & $1874-1732 \Omega \mathrm{m}$ \\
3 & $\square$ & $1732-2381 \Omega \mathrm{m}$ \\
\hline
\end{tabular}

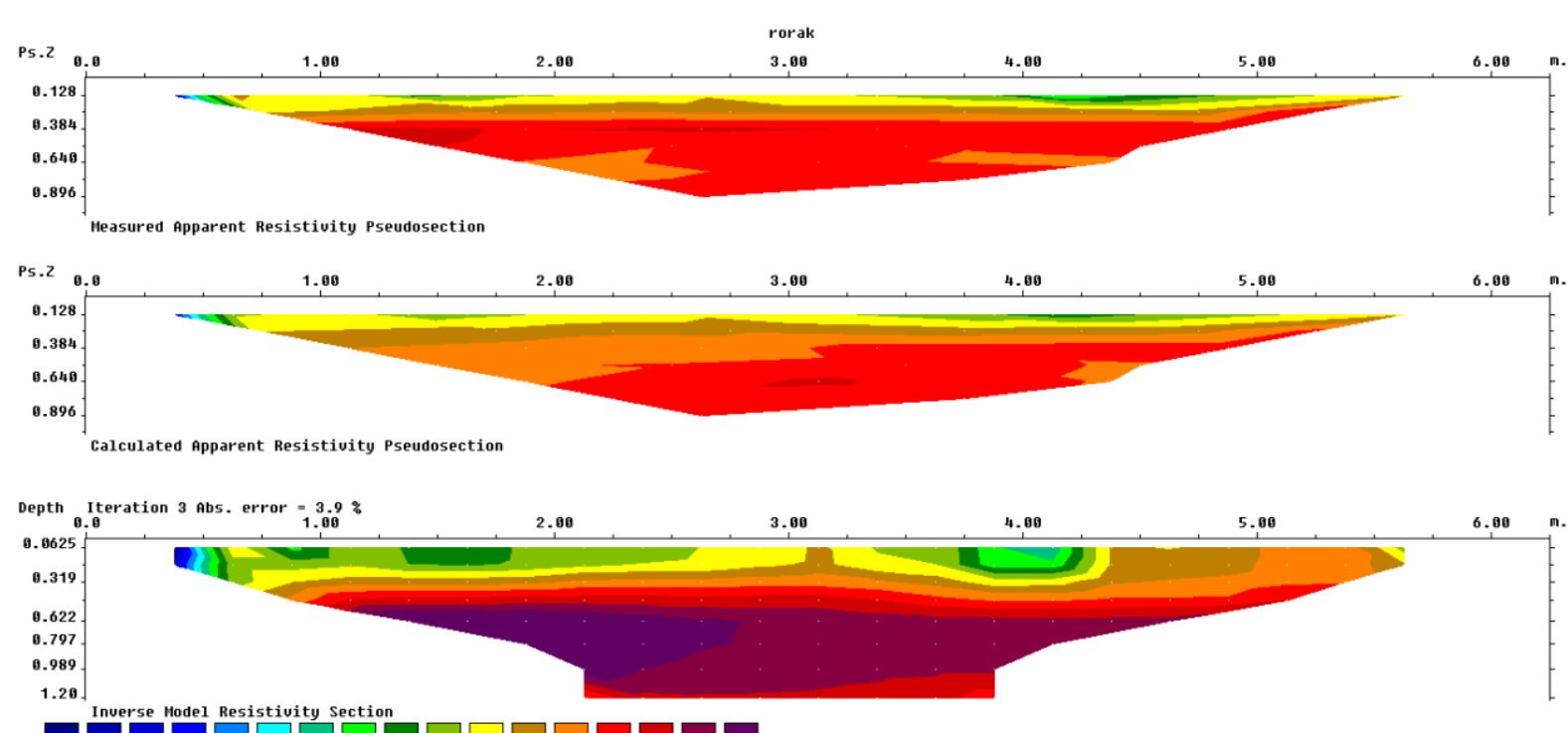

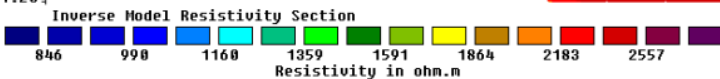

Figure 7. Track 2 without dead-end trench application

Notification for Figure 7. Interpretation result of track 2 without dead-end trench application

\begin{tabular}{lll}
\hline No. & Contour color & Resistivity value \\
\hline 1 & & $846-1168 \Omega \mathrm{m}$ \\
2 & & $1168-1846 \Omega \mathrm{m}$ \\
3 & & $1846-2557 \Omega \mathrm{m}$ \\
\hline
\end{tabular}


Table 5. Stomatal density, stomatal conductance, $\mathrm{H}_{2} \mathrm{O}$ content, $\mathrm{CO}_{2}$ leaf content, photosynthesis rate

\begin{tabular}{|c|c|c|c|c|c|}
\hline Treatment & $\begin{array}{l}\text { Stomatal density } \\
\quad\left(\text { unit } / \mathbf{m m}^{2}\right)\end{array}$ & $\begin{array}{c}\text { Stomatal } \\
\text { conductance } \\
\left(\text { unit } / \mathbf{m m}^{2}\right)\end{array}$ & $\begin{array}{l}\mathrm{H}_{2} \mathrm{O} \text { leaf content } \\
(\mathrm{mmol} / \mathrm{mol})\end{array}$ & $\begin{array}{c}\mathrm{CO}_{2} \text { leaf } \\
\text { content }(\mu \mathrm{mol} \\
\left.\mathrm{CO}_{2} / \mathrm{m}\right) \\
\end{array}$ & $\begin{array}{c}\text { Photosynthetic } \\
\text { rate }(\mu \mathrm{mol} \\
\left.\mathrm{CO}_{2} / \mathrm{m} / \mathrm{s}\right) \\
\end{array}$ \\
\hline \multicolumn{6}{|l|}{ Clones } \\
\hline RCC 70 & $1058.12 \mathrm{a}$ & $0.61512 \mathrm{a}$ & $45.4700 \mathrm{a}$ & $363.46 \mathrm{a}$ & $164.643 \mathrm{a}$ \\
\hline RCC 71 & $1056.24 \mathrm{a}$ & $0.61437 \mathrm{a}$ & $45.6350 \mathrm{a}$ & $363.46 \mathrm{a}$ & $164.643 \mathrm{a}$ \\
\hline KKM 22 & $1065.99 \mathrm{a}$ & $0.63890 \mathrm{a}$ & $45.6817 \mathrm{a}$ & $363.46 \mathrm{a}$ & $164.640 \mathrm{a}$ \\
\hline \multicolumn{6}{|l|}{ The dead-end trench } \\
\hline With & $1054.37 \mathrm{p}$ & $0.63989 \mathrm{p}$ & $47.4644 \mathrm{p}$ & $382.60 \mathrm{p}$ & $169.604 \mathrm{p}$ \\
\hline Without & $1065.86 \mathrm{p}$ & $0.60570 \mathrm{q}$ & $43.7267 \mathrm{q}$ & $344.33 q$ & $159.680 \mathrm{q}$ \\
\hline Interaction & - & - & - & - & + \\
\hline $\mathrm{CV}$ & 8.56 & 7.09 & 2.67 & 4.27 & 2.03 \\
\hline
\end{tabular}

Note: The value followed by the same letter in the same column shows no significant difference based on the LSD test at a significance level of $95 \%$.

Table 6. Transpiration, nitrate reductase activity

\begin{tabular}{lcc}
\hline Treatment & $\begin{array}{c}\text { Transpiration } \\
(\mathbf{m g} / \mathbf{g})\end{array}$ & NRA (mg/g) \\
\hline Clones & $4.35083 \mathrm{a}$ & $1.4642 \mathrm{a}$ \\
RCC 70 & $4.28100 \mathrm{a}$ & $1.4921 \mathrm{a}$ \\
RCC 71 & $4.29950 \mathrm{a}$ & $2.3812 \mathrm{a}$ \\
KKM 22 & & \\
The dead-end trench & $1054.37 \mathrm{p}$ & $2.2320 \mathrm{p}$ \\
With & $1065.86 \mathrm{p}$ & $1.3263 \mathrm{p}$ \\
Without & + & - \\
Interaction & 3.67 & 26.72 \\
CV & & \\
\hline
\end{tabular}

Note: The value followed by the same letter in the same column shows no significant difference based on the LSD test at a significance level of $95 \%$

\section{Physiology}

Stomatal density, stomatal conductance, $\mathrm{H}_{2} \mathrm{O}$ content, $\mathrm{CO}_{2}$ leaf content, photosynthesis rate

The dead-end trench application provided an opportunity for soil to store water. Water used for various physiological plant activities. Water served to maintain turgor pressure and gas exchange in stomata based on the water and soil environment. Water absorbed through the roots and moving into xylem vessels on the stems and on the leaves. Water transmitted from plants through stomata in surface areas (Beckett 2013).

Stomatal density had no difference between clones or the dead-end trench. The width of the leaf stomatal opening was known to be wider with the dead-end trench application. Stomatal Conductance under dead-end trench application was greater than without dead-end trench application. Measurement of $\mathrm{H}_{2} \mathrm{O}$ Leaf Content showed had no significant difference between clones RCC 70, RCC 71, and KKM 22. Application of dead-end trench reported had greater $\mathrm{H}_{2} \mathrm{O}$ leaf content. Carbon dioxide leaf content showed under dead-end trench application greater than field without trench, but had no significant difference between each clone. Clones RCC 70, RCC 71, and KKM 22 gave the same response of photosynthetic rate, but the application of dead-end trench successfully increased photosynthetic rate.
Tabel 7. Chlorophyll a, chlorophyll b, and total chlorophyll

\begin{tabular}{lccc} 
& \multicolumn{3}{c}{ Chlorophyl content (mg/g fresh leaves) } \\
\cline { 2 - 4 } Treatment & $\begin{array}{c}\text { Chlorophyll } \\
\text { a }\end{array}$ & $\begin{array}{c}\text { Chlorophyll } \\
\text { b }\end{array}$ & $\begin{array}{c}\text { Total } \\
\text { chlorophyll }\end{array}$ \\
\hline Clones & & & \\
RCC 70 & $0.50380 \mathrm{ab}$ & $0.12754 \mathrm{a}$ & $0.63134 \mathrm{ab}$ \\
RCC 71 & $0.42620 \mathrm{~b}$ & $0.11029 \mathrm{a}$ & $0.53649 \mathrm{~b}$ \\
KKM 22 & $0.53198 \mathrm{a}$ & $0.12465 \mathrm{a}$ & $0.65662 \mathrm{a}$ \\
The dead-end trench & & & \\
$\quad$ With & $0.47050 \mathrm{p}$ & $0.12497 \mathrm{p}$ & $0.59547 \mathrm{p}$ \\
$\quad$ Without & $0.50415 \mathrm{p}$ & $0.11668 \mathrm{p}$ & $0.62083 \mathrm{p}$ \\
Interaction & + & - & - \\
CV & 14.14 & 21.62 & 14.24 \\
\hline
\end{tabular}

Note: The value followed by the same letter in the same column shows no significant difference based on the LSD test at a significance level of $95 \%$

Transpiration, nitrate reductase activity, chlorophyll a, chlorophyll b, and total chlorophyll

Transpiration reported had no significant difference between clones RCC 70, RCC 71, and KKM 22, the greatest transpiration value was clone RCC 70. The same result occurred under dead-end trench treatments that showed had no significant difference. Nitrate reductase activity (NRA) had no significant difference between clones RCC 70, RCC 71, and KKM 22, the greatest NRA was under dead-end trench treatments. Chlorophyll a, total chlorophyll b, and total chlorophyll had no significant difference between the clones tested and in the dead-end trench application.

\section{Discussion}

Resistivity under soil profile provides resistivity data that illustrated the effective mapping and estimation of spatial variability of water and soil dynamics. This description used for precision agriculture. Electrical resistivity provided an approach to determine water content in soils and some soil properties that affect crop yields (Isola et al. 2018). The dead-end trench gave in the soil making low resistivity. Low resistivity (the blue color) indicated an ion breakdown, electric current was easier to conduct because there was no material resistance in the soil. The presence of water in the soil also causes lower 
resistivity. The resistivity geoelectric method used to determine the distribution of soil moisture in a section of land. Interpretation depended on the land geology (Williams et al. 2018). The existence of low resistivity was possible for many new roots to grow. Mechanical barriers in the form of texture and structure reduced. More root growth in tertiary and quartet roots in soils with low resistivity. Primary and secondary roots were found in soils with higher resistivity. The dead-end trench gave the soil had more water content so that there were many roots in the area.

Water content varies at each depth of the soil profile, roots took moisture by penetrating into new areas in the soil that had a higher water potential. The dead-end trench application roots cutting and trigger the new root hair growth. Apical dominance removed by cutting roots tip. The root extended by the cells extension behind the tip of meristem and the root width was the end cell enlargement produced the lateral meristem. The water availability in the dead-end trench allowing the roots to grow properly, cells from the meristem tip undergo roots expansion. Root differentiation zone was directly proportional to root growth. Cells at the border that regulate mitosis give signals to meristematic cells in the root cap. regulation of cell production provides great benefits for plants (Brigham et al. 1998).

The treatment given did not affect the $\mathrm{CO}_{2}$ content, it is in accordance with the opening conditions of the stomata and the stomata density which did not have a significant difference between treatments. Increased levels of $\mathrm{CO}_{2}$ in the air caused an increase in temperature and humidity. The rate of photosynthesis in this study was not affected by the various treatments given (Table 5). Photosynthesis induction was regulated by sub-processes such as RuBP regeneration, Rubisco activation, and stomata movement. Changed in mesophile conductance and non-photochemical blackouts in response to irradiation may further regulate photosynthetic dynamics and were also influenced by $\mathrm{CO}_{2}$ and leaf temperature. Activation of the Rubisco enzyme was very sensitive to $\mathrm{CO}_{2}$ content (Kaiser et al. 2014). Photosynthesis in $\mathrm{C} 3$ plants increases with increasing $\mathrm{CO}_{2}$ concentration in the air. Rubisco activity in mesophyll has increased quite high in response to an increase in air $\mathrm{CO}_{2}$. An increase in $\mathrm{CO}_{2}$ concentration, stimulates an increase in $\mathrm{CO}_{2}$ assimilation, growth and crop yields through decreased photorespiration activity and increased $\mathrm{CO}_{2}$ fixation by Rubisco.

The content of $\mathrm{CO}_{2}$ had an effect on transpiration. The phenomena of an increase in leaf-air vapor pressure deficit and decreased stomatal conductance and can affect the rate of carboxylation and Rubisco activation (Kaiser et al. 2014). The rate of transpiration was influenced by many environmental factors, it could be influenced by the presence of wind that was not too hard could increase the rate of transpiration. These conditions increased cytokinin levels in guard cells and vascular tissue in the leaves. Guard cell activity requires the exchange of water and ions with surrounding cells. Changed in turgor exert mechanical stress on the surrounding cells. The rate of transpiration can change the $\mathrm{pH}$ of xylem sap, which also affects the apoplastic $\mathrm{pH}$ of the leaves (Casson et al. 2007).

The content of $\mathrm{H}_{2} \mathrm{O}$ and $\mathrm{CO}_{2}$ leaves increased under the dead-end application and absorbing more water. Water used to stomata enclosure and maintained leaf turgor. Plants use $\mathrm{CO}_{2}$ for photosynthesis. The main function of stomata was maximized $\mathrm{CO}_{2}$ diffusion. Stomatal conductance decreased when $\mathrm{CO}_{2}$ increased should not necessarily mean decreasing transpiration in the canopy. Increasing leaf temperature forced the leaf increasing transpiration (Leakey 2009). There was an assumption that increasing $\mathrm{CO}_{2}$ in the atmosphere will reduce $\mathrm{O}_{2}$ uptake by plants, however, a study with six hundred measurements on nine species of plants conducted in Illinois on an increase in $\mathrm{CO}_{2}$ concentration over a long period of time indicates no decrease in $\mathrm{O}_{2}$ uptake of plant respiration (Davey et al. 2004).

The process of loss of plant water and stomata carbon dioxide exchange had a major role in stomata regulated photosynthesis and controlled transpiration. The relative changed in stomatal conductance provides a relative changed in the rate of transpiration (Jones 1999). Stomatal conductance had no trigger to high photosynthesis, but could be inducing adverse effects due to excessive water using (Lu et al. 1998). The dead-end trench was reported to trigger a higher photosynthesis rate. Clones RCC 70, RCC 71 , and KKM 22 reported had no significant difference in stomatal density, stomatal conductance, $\mathrm{H}_{2} \mathrm{O}$ leaf content, $\mathrm{CO}_{2}$ leaf content, and photosynthesis rate. Stomatal opening there was loss of plant water and decreasing the leaf potential. Water loss in plants was caused by transpiration through stomata. The stomatal opening and closure depend on the pressure of the plant cell turgor (Lestari 2005). Plant water absorption and movement were influenced by soil moisture, root contact with soil, and water soil resistance to water flow.

Transpiration occurred through stomata, wider stomatal opening triggered high transpiration. The guardian cell experienced loss of turgor when the moisture in the leaves lower. NRA allowed for estimation of nitrogen status in plants correlated with yield and plant growth. Nitrate reductase played a role in reducing $\mathrm{NO}_{3}$-into organic molecules. Plant nitrogen conditions were no different in the various clones tested. In research Garg and Singla (2005), there was a decrease in NRA under saline conditions causing the degradation of nitrate reductase or decreasing in enzymes synthesis rate. NRA reduction in leaf and root occurred proportionally to the reduction of the dry weight root and shoot accumulation. High radiation increased photosynthesis rate that was conducive to the enzyme nitrate reductase activity.

Inside chloroplast lamella, there were pigments, mostly in the form of chlorophyll a and chlorophyll b. Low chlorophyll content and high anthocyanin pigmentation from leaf expansion kept leaf temperatures low and reduced transpiration. Decreased transpiration rate caused by the leaves dense hair covering (Almeida and Valle 2007). Temperature and water were important factors in chlorophyll synthesis. Climate, soil, and phylogeny factors have little effect on chlorophyll variation in forest 
ecosystems. The existence of chlorophyll variations on a large scale was difficult to be used as the main input parameter ( $\mathrm{Li}$ et al. 2018). Low chlorophyll concentrations still absorbed enough light energy at high light intensities. High chlorophyll content became very important at low radiation intensity (Buttery and Buzzell 1977).

Plant leaves that grew with low light intensity usually had low levels of nitrate reductase. The activity of the enzyme increased when plants were moved under conditions of high light intensity. The intensity of light also affects the stability of the enzyme. The rate of reduction of nitrates in leaves was influenced by light in various variations (Anjani et al. 2006). ANR observations were not significantly different because the intensity of the light being held captive by plants also did not experience a difference. Nitrite production used in vivo testing depends on the diffusion of $\mathrm{NO}_{3}$-into the tissues to reach the cytoplasm where the enzyme was located. The nitrate reductase catalyst converts $\mathrm{NO}_{3}$-into $\mathrm{NO}_{2}{ }^{-}$by using $\mathrm{NADH}$ that comes from the oxidative respiration pathway. Under normal conditions $\mathrm{NO}_{2}{ }^{-}$was produced in green tissue that was transferred to chloroplasts and reduced to ammonia using ferredoxin obtained from photosynthetic electron transport (Cazetta and Villela 2004).

Lack of correlation between photosynthesis rate and crop yield in several studies because each plant genetically responds differently to photosynthesis. Carbon by $50 \%$ could be assimilated by leaves under limited light conditions for each different biochemistry and biophysics that determine the rate of photosynthesis. Increasing leaf area could be achieved by increasing leaf area per area. Increased leaf area, where shaded conditions, occurred causing photosynthesis rate to decreased because the sources spread more in the leaf area. Photosynthesis could be limited by the capacity of the bottom. The period after flowering was generally deep in the seed portion of the plant, namely the number and potential size of seed formation. The decreased in the capacity of the pit was induced by the removal of the seeds filling which caused decrease in the capacity of photosynthesis.

In conclusion, the results showed that the dead-end trench significantly increased total chlorophyll a, stomatal opening width, transpiration, and $\mathrm{H}_{2} \mathrm{O}$ leaf content, $\mathrm{CO}_{2}$ leaf content, and photosynthesis rate. The dead-end trench application significantly improves the physiology of the canopy of cocoa plants, based on the results of the resistivity geoelectric inversion. The conclusions in points 1 and 2 applied equally to the three tested cocoa clones, namely RCC 70, RCC 71, and KKM 22.

\section{ACKNOWLEDGEMENTS}

This study was supported by the Ministry of Research, Technology, and Higher Education of the Republic of Indonesia through Doctoral Dissertation grants Year 2019 No. 1176/UN1/DITLIT/DIT-LIT/2019; there are no major obstacles in conducting research.

\section{REFERENCES}

Adjaloo MK, Oduro W, Banful BK. 2012. Floral phenology of upper Amazon cocoa trees: implications for reproduction and productivity of cocoa. Int Scholarly Res Netw ISRN Agron 1: 1-8.

Alban MBKA, Apshara SE, Hebbar KB, Mathiaas TG, Severin A. 2015. Morpho-physiological criteria for assessment of two-month-old cocoa (Theobroma cacao L.) genotypes for drought tolerance. Indian J Plant Physiol 21: 15-165.

Almeida AAFD, Valle RR. 2007. Ecophysiology of the cacao tree. Braz J Plant Physiol 19: 425-448.

Anjani, Umar S, Iqbal M. 2006. Nitrate accumulation in plants, factors affecting the process, and human health implications: a review. Agron Sustain Dev INRA EDP Sci 27: 45-57.

Beckett RA. 2013. General principles of plant water relations. Prairie Soils Crops J 6: 107-117.

Brigham LA, Woo H, Wen F, Hawes MC. 1998. Meristem-specific suppression of mitosis and a global switch in gene expression in the root cap of pea by endogenous signals. Plant Physiol Am Soc Plant Biol 118 (4): 1223-1231.

Buttery BR, Buzzell RI. 1977. The relationship between chlorophyll content and rate of photosynthesis in soybeans. Can J Plant Res 57: 15.

Casson, A. Tacconi, L. and Deddy, K. 2007 Strategies to reduce carbon emissions from the oil palm sector in Indonesia. Paper prepared for the Indonesian Forest Climate Alliance, JakartaCazetta JO, Villela LCV. 2004. Nitrate reductase activity in leaves and stems of tanner grass (Brachiaria radicans Napper). Sci Agric (Piracicaba, Braz) 61 (6): 640-648.

Davey PA, Hunt S, Hymus GJ, Delucia EH, Drake BG, Karnosky DF, Long SP. 2004. Respiratory oxygen uptake is not decreased by an instantaneous elevation of $\mathrm{CO}_{2}$, but is increase with long-term growth in the field at elevated $\mathrm{CO}_{2}$. Plant Physiol 134 (1): 520-527.

Dimtsu GY. 2018. Technical evaluation of soil and water conservation measures in Maego Watershed, North Ethiopia. Afr J Environ Sci Technol 12: 177-185.

Fonkeng EE. 2014. Cocoa yield evaluation and some important yield factors in smallholder Theobroma cacao agroforests in Bokito-Centre Cameroon. Universite De Dschang. Cameroon.

Garg N. Singla R. 2005. Short communication nitrate reductase activity in roots and leaves of chickpea cultivars under salt stress. Spanish J Agric Res 3: 248-252.

Harborne AJ. 1998. Phytochemical Methods, Guides for Modern Ways to Analyze Plants. Springer, Netherlands.

Hidayat SR. 2009. Analysis of Characteristics of Stomata, Chlorophyll Content and Heavy Metal Content in Leaves of Tree Protectors in the Sidoarjo Mud Porong Area. Faculty of Science and Technology, Malang Islamic University, Malang. [Indonesian]

Isola AA, Olayanju GM, Lawrence S, Ewulo BS. 2018. Application of electrical resistivity method in monitoring influence of soil properties on the growth of Cucumis sativus. IOSR J Appl Geol Geophys 6: 0123.

Jones JW, Kenig A, Vallejos CE. 1999. Reduced state-variable tomato growth model. Trans ASAE 42 (1): 255-265

Kaiser E, Morales A, Harbinson J, Kromdijk J, Heuvelink E, Marcelis LFM. 2014. Dynamic photosynthesis in different environmental conditions. J Exp Bot 66 (9): 2415-2426.

Kurothe RS, Vishwakarma AK, Sena DR, Kumar G, Rao BK, Pande VC. 2014. Decision support system for contour trenching. Indian J Soil Conserv 41: 143-153.

Lahive F, Hadley P, Daymond AJ. 2019. The physiological responses of cacao to the environment and the implications for climate change resilience: a review. Agron Sustain Dev 39: 2-22.

Leakey ADB, EA Ainsworth, CJ Bernacchi, A Rogers, SP Long, DR Ort. 2009. Elevated $\mathrm{CO}_{2}$ effects on plant carbon, nitrogen, and water relations: six important lessons from FACE. J Exp Bot 60 (10): 28592876.

Lestari EG. 2005. The relation between stomata index and droughtresistant at rice somaclones of Gajahmungkur, Towuti, and IR 64. Biodiversitas 7 (1): 44-48.

Li YM, Elson M, Zhang D, Sicher RC, Li H. 2013. Physiological traits and metabolites of cacao seedlings influenced by Potassium in growth medium. Am J Plant Sci. 
Li Y, He N, Hou J, Xu L, Liu C, Zhang J, Wang Q, Zhang X, Wu X. 2018. Factors influencing leaf chlorophyll content in natural forests at the biome scale. Front Ecol Evol. DOI: 10.3389/fevo.2018.00064

Listyawati S. 1994. Effects of co 60 gamma radiation on nitrate reductase activity and anatomical structure Brassica campestris Linn. Faculty of Biology, UGM, Yogyakarta. [Indonesian]

Lu Z, RG Percy, CO Qualset, E Zeiger. 1998. Stomatal conductance predicts yield in irrigated Pima cotton and bread wheat grown at high temperatures. Journal of Experimental Botany, 49 (1): 453-460

Loveless AR. 1983. Principles of Plant Biology for the Tropics. Longman, London.

Rajoniati. 2006. The growth of side grafting buds of several clones at various heights of the main stem of the cocoa plant. Growth of Side Budding Buds. Agricultural Systems Postgraduate Program.Universitas Hasanuddin Makassar, Makassar.
Rolia E, Sutjiningsih D. 2018. Application of geoelectric method for groundwater exploration from surface (A literature study). AIP Conference Proceedings, 26 June 2018

Tang Q, He C, He X, Bao Y, Zhong R, Wen A. 2014. Farmers sustainable strategies for soil conservation on sloping arable lands in the upper Yangtze River Basin, Shina. Sustainability 6: 4795-4806.

Wickrama AM, Dunwell JM. 2018. Cacao biotechnology: current status and future prospects. Plant Biotechnol J 16: 4-17.

Wijaya AS. 2015. Application of the Wenner configuration resistivity geoelectric method to determine the soil structure in the SCC ITS Surabaya backyard. Indonesian Physics Journal 19: 1-5. [Indonesian]

Williams E, Ahenkorah I, Baffoe E, Awotoye TF, Ephraim GL, Asebiah DC. 2018. Application of geoelectric resistivity to determine soil moisture distribution. Am J Eng Res 7: 113-124. 